\title{
TENSILE STRENGTH AND MACRO-MICROSTRUCTURES OF A6061 CDFW WELD JOINT INFLUENCED BY PRESSURE AND HOLDING TIME IN THE UPSET STAGE
}

\author{
Farg Abdula M Abdulla ${ }^{1}$, Yudy Surya Irawan ${ }^{2}$,Djarot Bangun Darmadi ${ }^{2}$ \\ ${ }^{1}$ Azzawiya Oil Refining Company, Maintenance Department, Azzawiya, Libya. \\ 2 Mechanical Engineering Department, Faculty of Engineering, Brawijaya University \\ Jalan Mayjen Haryono 167, Malang, East Java, Indonesia 65145 \\ E-mail: fargabdulla@student.ub.ac.id,fargabdulla@gmail.com
}

\begin{abstract}
This paper aims to analyze the effect of pressure and holding time in the upset stage on tensile strength and macro-microstructures of continuous drive friction welded (CDFW) joints of aluminum alloys A6061. Friction weld specimens were welded using variations of upset pressure $(40,80,120 \mathrm{MPa})$. The upset holding time was varied from 3, 10, to 20 seconds. Tensile strength test was conducted based on the AWS standard. The result showed that the higher upset pressure and the longer holding time in the upset stage are able to reduce the porosity of the CDFW weld joint and cause a higher tensile strength of the specimens. Meanwhile, from macro-mic restructures observation results, it was found that the specimen with maximum tensile strength has a wider partly deformed area (ZPD) and finer grains in the center of the specimen longitudinal section compared to those of the specimens with minimum tensile strength. It was occurred due to plastic deformation as the result of the higher pressure and the longer holding time in the upset stage. Fracture surface observation results indicate that in the specimen with a higher upset pressure and a longer holding time, has inflated fracture surface and the fracture zone exists in the heat affected zone, not in the interface like that of the specimen with lower tensile strength due to the lower upset pressure and the shorter holding time.
\end{abstract}

Keywords: Aluminum alloys, Continuous Drive Friction Welding, Upset Pressure, Tensile Strength, Macro- Microstructures

\section{INTRODUCTION}

Aluminum is as a material, which is not easily joined because of its characteristic of high thermal conductivity and the presence of oxide on its surface. In regard to that, continuous drive friction welding (CDFW) as one type of friction welding plays a role as a solid-state welding method which preferable to solve the problem, because the process can eliminate the oxide in the surface as a flash that flows out from the interface [1].

There have been many studies on continuous drive friction welding (CDFW) in combining aluminum alloys, for example, A6061 which possesses good corrosion resistance, medium tensile strength, and good welding characters in many applications such as in cars, airplanes, and trains. One study analyzed the tensile strength of the welded joints generated by the rotating friction welding of spherical aluminum A6061 with different chamfer angles [2]. The result reported that the angle of the chamfer affects the tensile strength of $A 6061$ rotating friction welding joint with the 30-degree chamfer angle giving the maximum tensile strength.

In addition, another study discusses the effect of rotation variation and compression time on tensile strength and porosity of friction welding. The result showed that the material has three zones of the undeformed zone (UZ) which are almost as hard as the parent metal, plasticized zone (PZ), and partial deformation zone (PDZ). The hardness level in $P Z$ is the highest compared to that in PDZ and in UZ. The hardness in $P Z$ rises because of the zone's fine grain size [3]. Also, a study done for friction welding using Aluminum Alloy 6061T6 indicated a better result of friction welding compared with conventional welding in the porosity analysis. This is because the friction welding produced by welds hardly contains porosity [4]. Sathiya observed the friction welding by the use of the frictional pressure of 15-25 bar and forging pressure 35-45 bar and the main shaft speed of $1125 \mathrm{rpm}$ [5]. 
Moreover, another study reported the the aluminum alloy A6061 bar. Water was then material's ability in heat absorption that caused used as a coolant during the process. After a grain size gap in the connection area that, the machining surfaces were polished between the two material sides. Therefore, the and the rotating friction welding specimens, as contact surface area causes the range in the shown in Fig.1, were generated by rotating the heat generated in the connection process at the same time and pressure. Besides, the heat also affects the welded joint strength [6].

Many parameters bring impacts on the strength of friction welding joints, most likely in the CDFW process. They include friction time, rotational speed, friction pressure, burn off length, upset pressure, and shock resistance time [6]. Some researchers reported on the effect of rotational speed on the mechanical properties of the friction weld joint of steel $[7,8]$. Irawan et.al found that higher upset force can increase tensile [9] and torsion strength of Al-Mg-Si friction weld joint [10-12]. Meanwhile, tensile strength is as one important mechanical property for the components such as the shaft on the engine to ensure the strength and safety of the shaft on the engine. However, the effect of pressure and holding time in the upset stage on tensile strength are not uncovered yet in aluminum alloys A6061 friction weld. Therefore, this paper analyzed the result study on the effect of upset pressure and holding time on tensile strength and macromicrostructures of aluminum alloys A6061 continuous drive friction welded (CDFW) joint.

\section{EXPERIMENTAL METHOD}

The chemical composition of the round bar of Aluminum alloy A6061 is presented in Table 1.

Table 1. The chemical composition of aluminum alloys A6061 (\% of weight)

$\begin{array}{cccrrr}\text { Al } & \text { Mg } & \text { Si } & \text { Fe } & \text { Cu } & \text { Zn } \\ 97.749 & 0.810 & 0.530 & 0.250 & 0.160 & 0.0210\end{array}$

\begin{tabular}{cccccc}
\hline $\mathrm{Mn}$ & $\mathrm{Cr}$ & $\mathrm{Pb}$ & $\mathrm{Ti}$ & $\mathrm{Ni}$ & $\mathrm{Sn}$ \\
0.110 & 0.085 & 0.250 & 0.014 & 0.017 & 0.004
\end{tabular}

The controlled variables were $1600 \mathrm{rpm}$ spindle spin speed and $6 \mathrm{~mm}$ burn-off length. Tensile strength test was conducted based on AWS (American Welding Society) standard. During the manufacture of friction welding specimens, a saw machine was used to cut process on the lathe. The variables in this study include the upset pressure of $40,80,120$ $\mathrm{MPa}$ and upset retention time of $3,10,20$ seconds, as the independent variable. The controlled variables consisted of $1600 \mathrm{rpm}$ spindle rotational speed and $6 \mathrm{~mm}$ burn-off length. The test of the tensile strength was performed following the AWS (American Welding Society)[13].

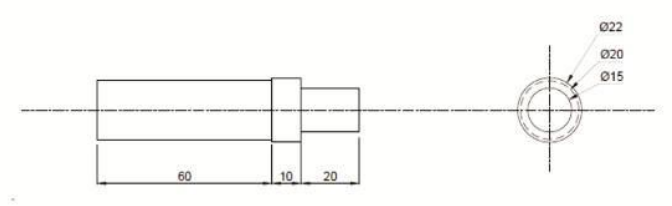

(a) Rotated part

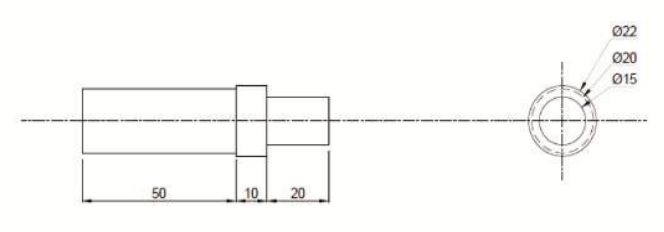

(b) Stationary part

Figure 1. The geometry of A6061 friction weld specimens

In a continuous process of drive friction welding, the left rod was gripped by a chuck connected to a rotating electric motor at a speed of $1600 \mathrm{rpm}$. Whereas, the right rod was also gripped in a chuck which is able to provide $120 \mathrm{MPa}$ compression pressure from the hydraulic pump system. Prior to the beginning of the friction welding process, the two contact surfaces of the specimen were cleaned with acetone. Welding was done by involving two parts for $6 \mathrm{~mm}$ burn of length (BOL); and once the $\mathrm{BOL}$ was reached, the spinning machine was turned off, and the rod on the right was continuously pressurized at 40, 80, $120 \mathrm{MPa}$ for 3, 10, 20 seconds. Furthermore, the welded specimen was cooled in air. At the time of the CDFW process, using an infra-red thermal gun the temperature on the CDFW flash was measured to monitor the input heat and the correlation to the CDFW joint tensile strength. 
The test specimens as illustrated in Figure 2 were proceeded in a machine on the lathe with water as a coolant for the tensile strength. The friction of the welded joint lies at the center of a testing specimen of the tensile strength. The tensile strength test was performed on AWS B4.0:2007 [13]. The tensile strength test was conducted employing a universal test machine with a crosshead speed of $2 \mathrm{~mm} / \mathrm{min}$. Moreover, the porosity of the specimen was measured using the Pycnometric method prior to the process of the tensile strength test.

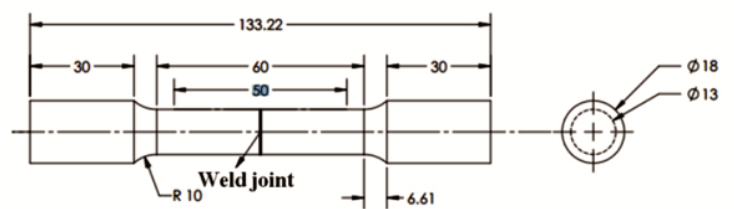

Figure 2. The geometry of $A 6061$ tensile strength test specimens (dimensions in $\mathrm{mm}$ ) [13]

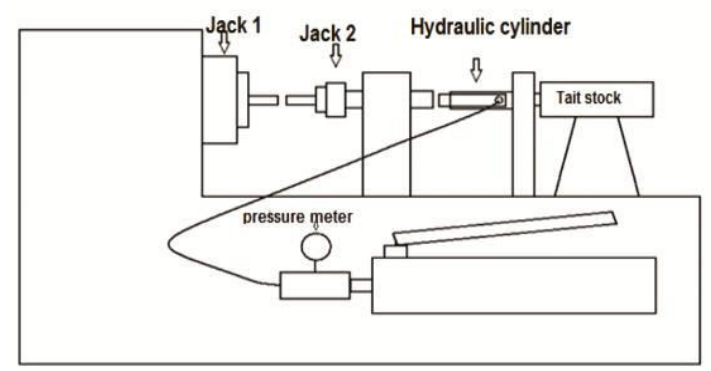

Figure 3. Friction Welding Tool Scheme

Figure 3 illustrates a simple friction welding machine. At the right moment, the rotation is halted and between the two components is a force applied. The pressure and heat combination creates a solid state bond at the interface of two merges [8].

\section{RESULT AND DISCUSSION}

The relationship among the joint CDFW tensile strength, setup pressure and holding time is depicted in Figure 4. As seen for any retention time, acceleration in upset pressure can cause a rise in the tensile strength of CDFW joint. Longer holding times provide adequate time to strengthen a more perfect metal bond in the interface. Maximum tensile strength is found on specimens with a shake pressure of $120 \mathrm{MPa}$ and a hold time of 20 seconds. Meanwhile, minimal tensile strength is found in specimens with setup pressure of $40 \mathrm{MPa}$ and a hold time of 20 seconds. It indicates that a higher interference pressure may cause a higher level of plastic deformation at the interface, followed by a longer hold time at the interference stage making the metal bond in the interface stronger.

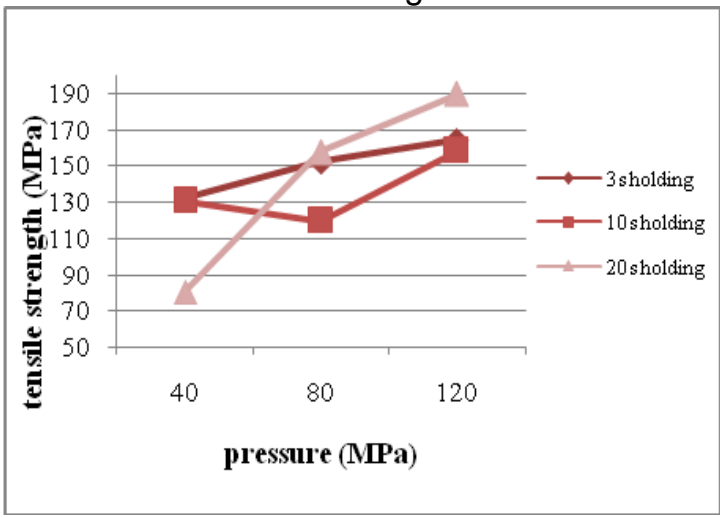

Figure 4. The tensile strength of A6061 friction weld specimens influenced by upset pressure and holding time.

The porosity test on the CDFW joint is illustrated in Figure 5. The result shows that when the upset pressure implemented on the specimen is higher, the porosity of the weld joint goes smaller. Similarly, a longer upset holding time reduces the weld joint porosity. This indicates that a higher upset pressure and longer retention time provide more energy to the compressed interface in order to make cavity occur from the specimen flash. The less porosity brings positive impact for increasing the CDFW joint strength.

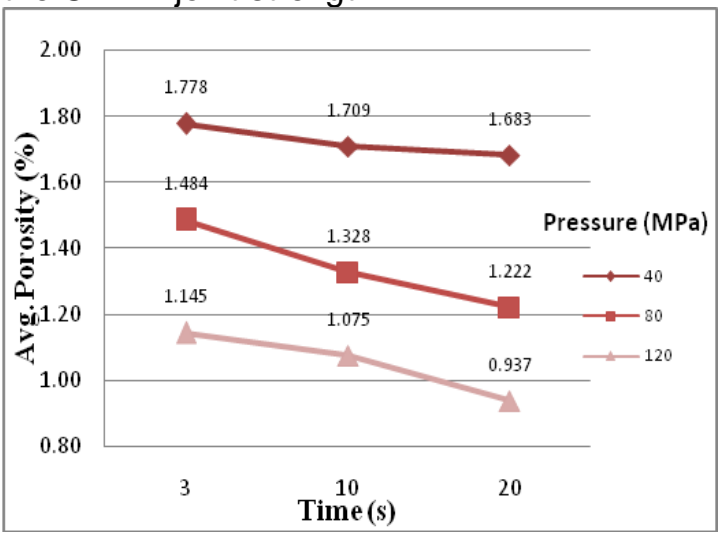

Figure 5. The porosity of $A 6061$ friction weld specimens under the effect of upset pressure and the holding time. 
The heat input during the CDFW process can be evaluated from the temperature of CDFW interface flash. Figure 6 shows the temperature cycle on the flash of the CDFW joint that has high tensile strength $(120 \mathrm{MPa}$ upset pressure) and low tensile strength (40 $\mathrm{MPa}$ upset pressure). It can be seen that the temperature of the specimen with higher upset pressure is slightly higher than that of the specimen with lower tensile strength. The higher temperature is due to higher mechanical energy that applied by the higher upset pressure that causes a higher degree of plastic deformation.

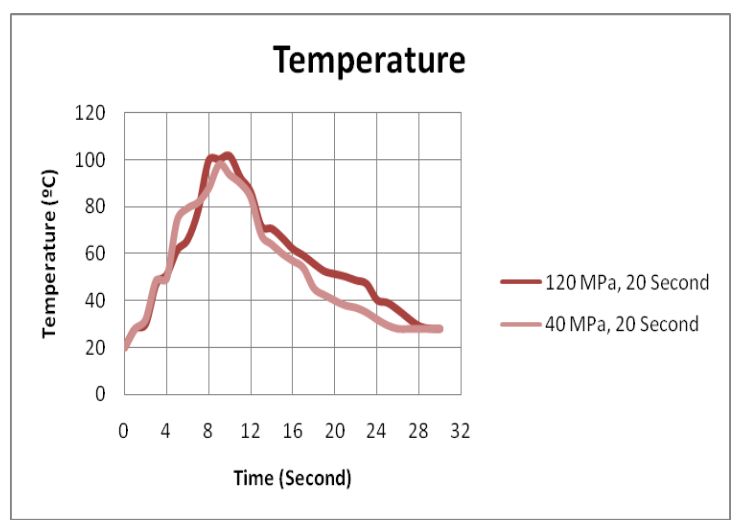

Figure 6. Flash temperature cycle for a specimen with high and low tensile strength, $120 \mathrm{MPa}, 40 \mathrm{MPa}$ upset pressure respectively

Figure 7 and 8 shows the microstructures of the center of the friction weld specimen with the highest and the lowest tensile strength. It can be seen that grain of specimen with the highest tensile strength as the result of 120 $\mathrm{MPa}$ upset pressure and 20 seconds holding time is smaller or finer than that of the specimen with the lowest tensile strength (Figure 8). It is thought that due to higher upset pressure can make a higher degree of plastic deformation so that the grain becomes smaller. Longer holding time give time more to the weld joint to be united longer to form metallic bonding under condition of high plastic deformation.

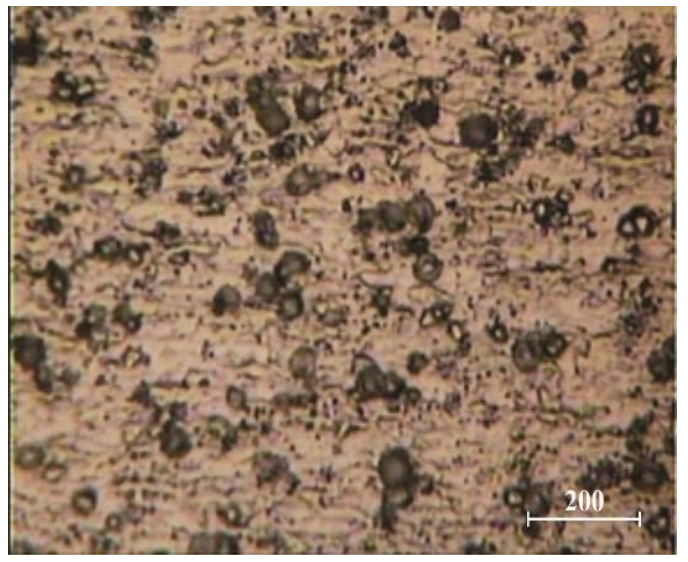

Figure 7. Photo microstructure of the specimen with highest tensile strength: a highest tensile strength with the upset pressure of $120 \mathrm{MPa}, 20$ seconds holding time and magnified photo $400 x$ (scale in $\mu \mathrm{m}$ ).

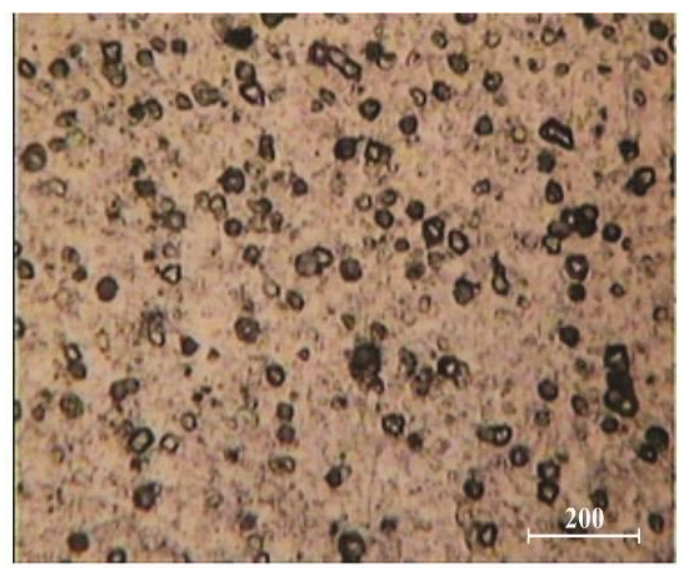

Figure 8. Photo microstructure of the specimen with the lowest tensile strength on the center A6061 welding joint: a lowest tensile strength with the upset pressure of $40 \mathrm{MPa}, 20$ seconds holding time and magnified photo $400 x$ (scale in $\mu \mathrm{m}$ ).

Figure 9 and 10 are longitudinal section macrostructures of CDFW specimens with holding time of 20 seconds and upset force of $40 \mathrm{MPa}$ of the CDFW joint specimen with low tensile strength and $120 \mathrm{MPa}$ upset pressure and 20 seconds holding time which has maximum tensile strength. It can be seen that both sizes of $\mathrm{Zpl}$ are the same, but the Zpd size of the specimen with maximum tensile strength is wider (Figure 10) than that of the specimen with lower tensile strength (Figure 9). 
The differences between the macrostructure surfaces and Zpd size of the specimens are the result of the upset pressure and holding time during the CDFW process.
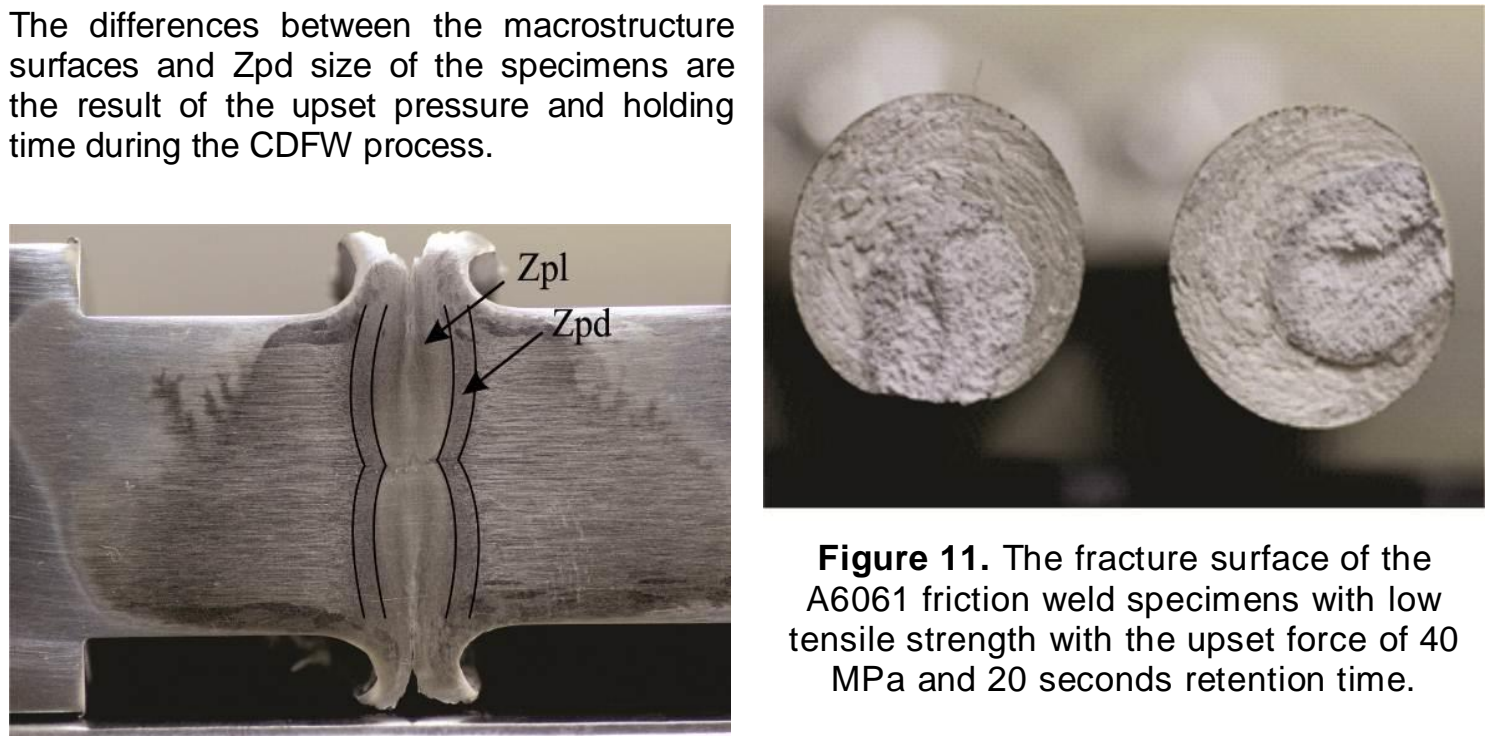

Figure 11. The fracture surface of the A6061 friction weld specimens with low tensile strength with the upset force of 40 $\mathrm{MPa}$ and 20 seconds retention time.

Figure 9. Longitudinal section macrostructure of CDFW specimen with holding time of 20 seconds and upset pressure of $40 \mathrm{MPa}$.
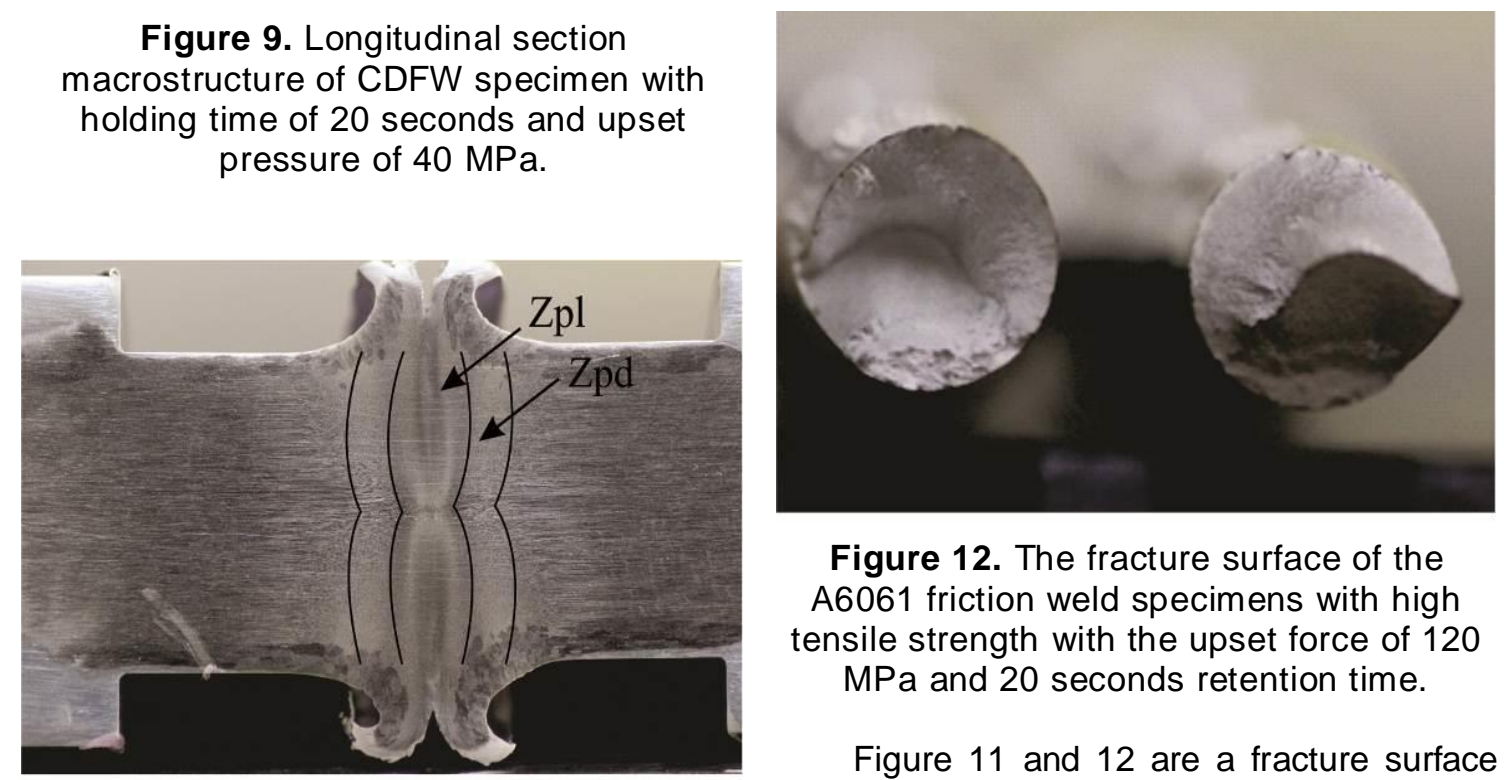

Figure 12. The fracture surface of the

A6061 friction weld specimens with high tensile strength with the upset force of 120

$\mathrm{MPa}$ and 20 seconds retention time.

Figure 10. Longitudinal section macrostructure of CDFW specimen with holding time of 20 seconds and upset pressure of $120 \mathrm{MPa}$.

Figure 11 and 12 are a fracture surface photo of a CDFW joint specimen with high and low tensile strength. It can be seen in Figure 11 that there is a spinning-like mark that can be observed on a flat fracture surface. This shows that the specimen fractured in the interface where spinning occurs. Meanwhile, specimens with high tensile strength have a fracture surface without spiral marks and nonflat fracture surface. This is also confirmed by measuring the location of the fracture that the specimen is not cracked at the interface but in the heat affected zone. The difference from the surface of the specimen fracture is caused by the upset pressure and hold time during the CDFW process which higher upset 
pressure and holding time yield strong metallic bond in the interface.

\section{CONCLUSIONS}

In summary, there are three major conclusions in this study, including:

1. The pressure and holding time in the upset stage affected the tensile strength and macro-microstructure and tensile strength of the A6061 CDFW joint.

2. The higher upset pressure and longer holding time were able to increase the CDFW specimen tensile strength because of the higher heat input and the existence of plastic deformation in the interface.

3. The maximum tensile strength of the A6061 CDFW joint was found in the specimen with the upset pressure of 120 $\mathrm{MPa}$ and holding time of 20 seconds, which has wider partly deformed plastic zone (ZPI) and finer grains in the interface.

\section{REFERENCES}

[1] Olson, D.L., Siewert, A., Thomas, A., Stephen, L., and Edward, G.R., 1993, ASM Handbook: Welding, Brazing, and Soldering, Vol. 6, ASM International, New York.

[2] Irawan, Y.S., Wirohardjo, M., and Ma'arif, M.S., 2012, Tensile Strength of Weld Joint Produced by Spinning Friction Welding of Round Aluminum A6061 with Various Chamfer Angles, Advanced Materials Res., vol. 567, pp. 761-765.

[3] Sathiya, P., Aravindan, S., and Noorul Haq, A., 2007, Effect of Friction Welding Parameters on Mechanical and Metallurgical Properties of Ferritic Stainless Steel, Int. J. Adv. Manufacturing Tech., vol. 31, no. 11-12, pp.1076-1082.

[4] Jiang, W.H., and Kovacevic, R., 2004, Feasibility Study of Friction Stir Welding of 6061-T6 Aluminum Alloy with AISI 1018 Steel Proc. of the Institution of Mechanical Engineers, Part B, Journal of Eng.Manuf., vol. 218, Iss.10, pp. 1323-1331.

[5] Sathiya, P., Aravindan, S., and Noorul Haq, A., 2004, Friction welding of austenitic stainless steel and optimization of quality, Proceeding Int. Symp. Res, Students on Materials Science and Engineering, pp. 1-10.
[6] Spindler, D.E., 1994. What industry needs to know about friction welding, Welding Journal, March, pp.37-42.

[7] Ozdemir N., 2005, Investigation of the mechanical properties of friction-welded joints between AISI 304L, AISI Steel as a function rotational speed. Mater Lett, Vol. 59, pp. 2504-2509.

[8] Ozdemir N., Sarsilmaz F., and Hascalik A., 2007, Effect of rotational speed on the interface properties of friction-welded AISI 304L to 4340 steel. Mater, Vol. Des 28, pp. 301-307.

[9] Santoso, E.B., Irawan, Y.S., Sutikno, E., 2012, Pengaruh Sudut Chamfer dan Gaya Tekan Akhir terhadap Kekuatan Tarik dan Porositas Sambungan Las Gesek pada Paduan Al-Mg-Si, Jurnal Rekayasa Mesin, Vol.3.No.1, pp.293-298.

[10] Tyagita, D.A., Irawan, Y.S., Suprapto, W., 2014, Kekuatan Puntir dan Porositas Hasil Sambungan Las Gesek AIMg-Si dengan Variasi Chamfer dan Gaya Tekan Akhir, Jurnal Rekayasa Mesin, Vol.5.No.1, pp.69-74.

[11] Irawan, Y.S., Amirullah, M., Gumilang, G.B.D., Oerbandono, T., and Suprapto, W., 2016, Torsion Strength of Continuous Drive Friction Weld Joint of Round Bar Aluminum A6061 Affected by Single Cone Geometry of Friction Area, AIP Conference Proceedings 1717, pp. 040010-1 - 040010-6.

[12] Irawan, Y.S., Suprapto, W., Oerbandono, T., January, A.R., Wijaksono, A.K.M., and Fauzan, R., 2017, Torsion strength of Round Bar A6061 Friction Weld Joint Influenced by Friction Time, Upset Force and One Side Cone Geometry, Journal of Environmental Engineering \& Sustainable Technology, Vol.4, No.02, pp.78-84.

[13] American Welding Society, 2007, AWS Standard B4.0:2007. 